\title{
R\&D Expenditures And Investors' Perception For An Input On Innovation Creation And Firm Growth: Empirical Evidence From Athens Stock Exchange
}

Panayiotis Tahinakis, University of Macedonia, Greece Michalis Samarinas, University of Macedonia, Greece

\begin{abstract}
The question that the present study attempts to examine, concerns whether investors value the potential of Greek enterprises to produce innovation, in a way that it could lead them to higher productivity, profitability and future growth. An answer to such a question, seems to bear significance for a country that tries to understand the reasons for an underachieving economy, struggling for growth, both macro and microeconomic. If the answer is positive, this means that investors are affected in their decision for buying or selling a stock by the growth prospect that innovation, expressed with $R \& D$ spending, creates for an enterprise. $R \& D$ expenditures are used in this study, since they represent the enterprise's input for the creation of innovation (Acs \& Audretsch, 1988) and therefore, the effort for future development and firm growth. The approach employed, follows the same rationale as Green et al, (1996) and Stark and Thomas (1998) do. The $R \& D$ data that we have utilized, are collected from all the Athens Stock Exchange, (henceforth ASE), public firms for the period 2005-2010 that spend on $R \& D$. The results, unlike previous research, depict a strong negative relation between $R \& D$ expenditures and stock price. In other words, investors in this Eurozone country do not consider $R \& D$ expenditures to be creators of innovation that will result in future growth, but they seem to be affected negatively in their assessment of the firm's financial condition by $R \& D$ spending.
\end{abstract}

Keywords: R\&D Expenditures; Investors Perception for Growth; Athens Stock Exchange

\section{INTRODUCTION}

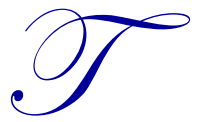

he ability of an enterprise to produce knowledge ${ }^{1}$ and innovation of any form is theoretically considered to be a key element, for the development of any enterprise. It means that there is a potential inflow of future benefits to the firm, resulting from an innovation input, like R\&D expenditures that could lead to growth, an increase in firm's profitability and consequently a rise of firm's value (Fama \& French, 1998). The production of knowledge and innovation is not only considered a potential asset for the enterprise, but also the creator of positive externalities and growth for the economy as a whole, (Arrow, 1962; Grossman and Helpman, 1991; Howwitt, 1999; Arnold, 2000; Funke and Strulik, 2000).

Of course, the issue at hand is not so much about whether corporate innovation can produce future benefits for a firm, but whether this is a belief shared by those that invest in it. Specifically, the question that is generated especially for an economy such as the Greek one that is in need of growth, both in microeconomic and macroeconomic level, is whether one of the most important inputs of innovation's production, which is considered to be R\&D expenditures, (Acs \& Audretsch, 1988; Mairesse \& Mohnen, 2002; Brown et al, 2009), is actually acknowledged as a creator of future benefits and firm prosperity, by the investing public. 
Keeping in mind these remarks, this study focuses on R\&D expenditures, since they constitute the initial event in a chain of events that can potentially result to the creation of value. Namely, the R\&D generated innovation $^{2}$, for a firm engaging in R\&D spending, results in an increase on firm's assets and more specifically on Intangible Assets. According to IFRS provisions ${ }^{3}$, a potential satisfaction of specific recognition criteria ${ }^{4}$, allows for $\mathrm{R} \& \mathrm{D}$ expenditures to be capitalized and treated as a firm's asset.

Specifically, there is a two-phase procedure concerning the expenditures pertaining to the creation of an Intangible Asset, internally. The first phase refers to the expenditures that are considered to be analogous to the Research activity. The accounting treatment of these research costs is for them to be expensed immediately.

The second phase in the creation of an Intangible procedure is the Development phase. If the costs incurred during this phase, meet the above mentioned recognition criteria, then they are capitalized creating an Intangible with a value equal to the sum of the development expenditures, from the day of recognition ${ }^{5}$, up until the end of the fiscal year.

What is even more interesting, is that investors in developed economies, treat those exact $R \& D$ expenditures as an item that comprises value, either they are capitalized, or not (Green et al., 1996). This specific reaction of investors towards these costs can help us realize the importance of R\&D expenditures, for the creation of innovation as one of its primary inputs.

For this reason the scope of this study, can be described as an empirical search of the effect that R\&D expenses have on the investing public in Greece and consequently on Greek stock market prices. We search for evidence of whether Greek investors are interested and therefore value the creation of innovation, as a source of future benefits and growth for the enterprise and subsequently for the whole of the economy.

This research perspective becomes even more interesting, if we investigate whether there is a significant amount of innovation input in Greece, before trying to examine its value relevance for the investors. For this reason, we examine some data, comparing R\&D expenditures from Greek business sector, with similar data from Euro Zone area and European Union (27 countries) average.

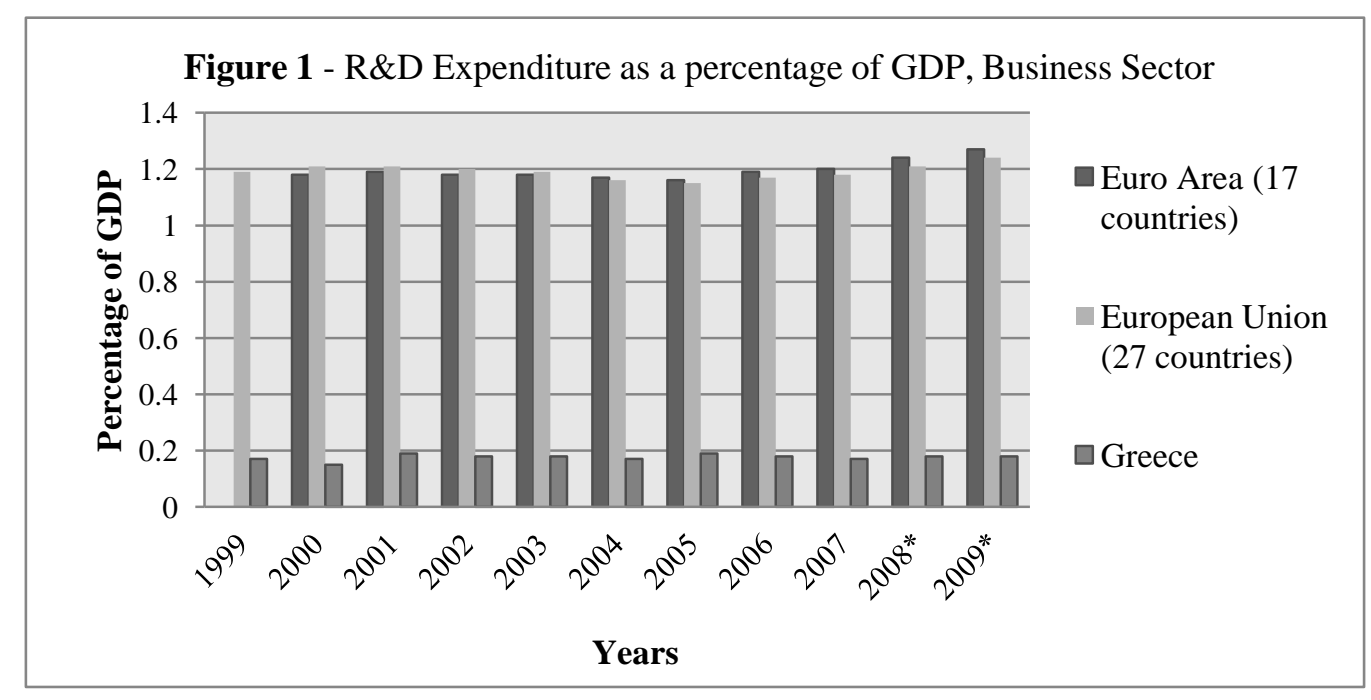

We can observe, in Figure $1^{6}$, that Greek business sector seems to spend only a small amount of money in $\mathrm{R} \& \mathrm{D}$ as innovation input. Greece, is not only quite below the EU and Euro zone R\&D average, but also remains substantially distant from the Lisbon treaty target of 3\%, that was supposed to be reached until 2010. Greece's spending on $\mathrm{R} \& \mathrm{D}$ is averaging $0.17 \%$, in contrast with $1.19 \%$ that is the EU and Euro area average. Some may argue that this has to do with the small size of the market and the relevantly small size of the enterprises in Greece that cannot spend so much in their effort to create innovation. 
This relatively small amount of R\&D spent by the Greek business sector may mean that investors in Greece perceive input for innovation, as expressed with $R \& D$ expenditures, with either of two different perceptions. Either the small magnitude of business sector R\&D raises doubts for the ability of Greek firms to create innovation, and consequently grow and raise value, or perhaps the fact that $\mathrm{R} \& \mathrm{D}$ expenses are rare, is interpreted, by the investors as providing firms with a relative advantage. This would mean that created innovation, translates into comparative advantage and consequently in higher profits, value, growth and finally stock returns. Thus, it is obvious that the small amount of R\&D expenses as a proportion of GDP raises some specific questions that constitute the core of our study.

The structure of the remainder of the study is formulated as follows: Section 2 provides a review of previous research and literature on subjects related with market valuation of R\&D expenses, while section 3 elaborates on methodological issues. Section 4, presents the data and describes the sample structure, while section 5 analyses the empirical results found. Finally, Section 6 provides the concluding remarks of our research.

\section{PREVIOUS RESEARCH}

Many researchers dealt with the valuation of intangibles and the investments on creation of innovation (R\&D expenses). A significant number of these studies reach the conclusion, that investors attribute value to $R \& D$ expenditures, since future benefits are expected. In other words, the more an entity invests in order to create and reproduce knowledge and innovation through $R \& D$, the more investors anticipate gaining in the future.

Prior research, deals with valuation of R\&D expenditures and whether or not investors appraise the potential creation of intangible value. This concept is adopted by Hirschey (1982) and Hirschey \& Weygandt (1985) in their research. In both studies, the dependent variable of the regression model is the stock price, while the independent comprise of the profits, $R \& D$ expenses, advertising expenses and variables like risk, (beta coefficient) and sector's growth. Especially, in Hirschey \& Weygandt's (1985) research the dependent variable is the market value, divided with the replacement value of tangible assets (Tobin's indicator (q)), while in the case of independent variables, they utilize intense $R \& D$ and advertising expenditures, or in other words $R \& D$ and advertising expenses divided by total sales. Both researches seem to conclude, that $R \& D$ expenditures constitute an indicator for stock price. Hirschey (1985), taking this one step further, employs a slightly alternative approach, using the excess valuation ratio, which can be calculated as market value, minus book value, divided by total sales. Intense R\&D and advertising expenditures, risk, enterprise's growth, market share of a firm, are used as independent variables. Once more he concludes that investors seem to treat R\&D expenses as worth of value.

Hirschey \& Spencer (1992) and Chauvin \& Hirschey (1993\&1994) reach the same conclusions on their own research. The only difference that seems to exist in the above mentioned studies is that the coefficient of R\&D expenditures may vary according to firm's size or activity (production or commercial). Sougiannis (1994) focuses on total performance of $\mathrm{R} \& \mathrm{D}$ expenses. Namely, he deals with those expenses as if they are investments on intellectual capital and attempts to understand whether or not, investors interpret them in the same way. He concludes that only current $\mathrm{R} \& \mathrm{D}$ expenses are considered creators of value by the investors and only for the present.

Chan et al, (1990) using the event study methodology, researched the change in stock prices when an announcement of augmented R\&D expenditures, occurs. The conclusions of this study depict, that these announcements seem to trigger the rise of stock prices, even though the enterprise might have recorded losses. Hence, according to the researchers, the investors seem to value and consider these expenses as of great importance, treating them as long-term investments that contribute to the entity's value.

In 1996, two different studies of Lev \& Sougiannis and Green et al., reach similar conclusions with the above mentioned. On the one hand, Lev \& Sougiannis conclusions depict that R\&D expenditures induce higher performances and argue for the capitalization of these expenses. On the other hand, Green et al. suggest that R\&D expenditures market value is treated by the investing public, as expenses for acquirement of assets and not just like operational expenditures. Oswald and Zarowin in 2007 also deal with a similar topic and examine the informative value of capitalized $R \& D$ expenditures. They provide evidence that capitalized $R \& D$, bears informative value significant for the investors, while Oswald (2008), takes this one step further and in contrast to Lev \& Sougiannis 
findings, he concludes that both firms, that either capitalize R\&D, or expense them, present rather equal value relevance. Stark \& Thomas, (1998), come up with results that validate the Green et al. findings, using a similar approach. Chan et al (2001) and Al - Horani et al (2003), deal with the same question and they argue that entities which either had bad performance in the past, or were $R \& D$ intensive ${ }^{7}$ are underestimated, (because the $R \& D$ expenses appear in the income statement rather than the balance sheet), or have abnormal returns in future financial years, which clearly depicts the importance that $R \& D$ expenses have for the investors.

Moreover, Franzen and Radhakrishnan (2009) using a residual income valuation framework, examine the informative value that investors attribute to R\&D expenditures, for firms that present profits and losses. Consistent with previous studies, $R \& D$ expenditures affect stock prices for both firms that disclose profits and losses. Kallunki et al. (2009), investigate whether a firm can amplify the effect that R\&D expenditures create in its market valuation by M\&As, regarding technology oriented firms. Their results depict, that the R\&D expenditures effect on firm's market valuation is indeed amplified, but only when two technology - oriented firms proceed to M\&A.

Palmon \& Yezegel in 2010 provide empirical evidence about the effect, that high R\&D intensity can have to the financial analyst's opinion and whether this is important enough to make them alter it, or revise it. The results of this study suggest, that analyst's opinion for R\&D intensive firms, despite the information asymmetry and complexity that high R\&D expenditures produce, present more valuable recommendation revisions.

Of course, it is of essence to mention the existence of studies that seem to contradict the above mentioned conclusions. Chambers et al (2002) in their research argue that high future returns that are sometimes associated with high $R \& D$ expenditures, might derive from the failure of uncertainty tests of R\&D expenses. Kothari et al. (2002), present evidence about the uncertain creation of value from R\&D expenditures. This research provides evidence, indicating that the uncertainty of the R\&D expenses' value, is by far bigger than the one accompanying expenses meant for other types of investments. Hence, those two different kinds of expenses should not be confused.

Furthermore, some researchers argue about whether or not they should take under consideration samples from firms of all sectors. In this manner the value attributed to R\&D costs seems to be questioned. For example, Ely et al. (2003) conclude that R\&D expenses in biotechnology sector are not statistically significant; therefore their change in size does not influence investors' decisions. In the contrary, Hand (2005) and Xu et al (2007) end up with the opposite conclusions.

Although a great number of studies argue that R\&D expenditures hold value for the investing public, there are some contradictory findings, indicating that the subject needs further investigation.

Many of the above mentioned methodologies have been applied utilizing UK and US data samples. These are two countries with developed economies, which emphasize on creation of knowledge, innovation and its reproduction as it is expressed with $R \& D$ expenditures. In such economies it becomes evident to the investors that innovation is an essential factor for the firm's development, at least according to the findings of the majority of previous studies. Firm's resources spent on input for innovation (R\&D expenditures), are considered money well spent, initiating a flow of future benefits. Hence, it seems logical for these investors, to anticipate that the value of an enterprise would rise as a consequence of an $R \& D$ expenses increase, treating them as investments to acquire assets. So the question at hand, attempts to examine economies with firms, spending fewer resources for the creation of innovation. Keeping this reasoning as our background we attempt to address this issue for Greece.

\section{METHODOLOGY}

The methodological approach of this study focuses on attempting to investigate whether stock prices, reflecting the decisions and attribution of value by the investors, can be influenced by R\&D expenditures which constitute inputs for corporate innovation and potential growth. Moreover this methodology can be utilized to clarify, whether the treatment of the investing public towards R\&D expenses, is one of investments in assets that will lead to future benefits, or of regular operational expenses. This research is based in the same rationale with the approach of Stark \& Thomas (1998), Green et al (1996), and Ohlson (1995), trying to test whether R\&D expenses can constitute an explanatory variable for stock prices. 
We must underline the fact that our study is an exploratory research. Therefore, we don't provide hypotheses, since the research conducted, aims in providing potentially useful insight into a given situation such as the Greek economic reality.

For our multivariate regression analysis, we employ share deflated variables in order to control for scale related effects ${ }^{8}$ (Barth \& Clinch, 2009). The dependent variable in our analysis will be the stock price. This variable is crucial for our model, since it reflects the value of an entity and incorporates the informative value attributed by the investors. Our first equation, following Stark \& Thomas' methodological rationale, depicts the linear relation between the closing stock price of an entity on the last day of March for year $t+1^{9}\left(\mathrm{P}_{\mathrm{t}, \mathrm{j}}\right)$ and earnings per share $\left(\mathrm{EPS}_{\mathrm{t}, \mathrm{j}}\right)$ for year $\mathrm{t}$ and firm $\mathrm{j}$.

$$
P_{t, j}=a_{0}+a_{1} E P S_{t, j}+e_{t, j}
$$

EPS includes the dilutive influence of R\&D expenses value, since during the preparation of the firm's income statement and in order for the net earnings to be estimated, it is necessary to subtract R\&D expenses. For this reason and in order to proceed, it seems reasonable to remove their influence from earnings and examine them as a separate variable following the methodology of Green et al (1996) and Stark \& Thomas (1998). In other words, since $R \& D$ expenses are deductable elements of net income on the income statement, we should add them to EPS in order to eliminate their dilutive effect and investigate the R\&D expenses effect to the stock price, independently. Our goal, utilizing such a distinction is to potentially improve the ability to explain stock price. So, equation (1) with the addition of these two new variables transforms as follows providing us equation (2):

$$
P_{t, j}=a_{0}+a_{1}\left(E P S_{t, j}+R D P S_{t, j}\right)+\alpha_{2} R D P S_{t, j}+e_{t, j}
$$

The variable $\mathrm{RDPS}_{\mathrm{t}, \mathrm{j}}$, represents the research and development expenses for year $\mathrm{t}$ and firm $\mathrm{j}$, expressed in a per share form. EPS+RDPS, constitute earnings per share plus research and development expenditures per share, for year $t$ and firm j. Summarizing equation (2), results in equation (3) that is depicted as follows:

$$
P_{t, j}=a_{0}+a_{1} E B R D_{t, j}+\alpha_{2} R D P S_{t, j}+e_{t, j}
$$

Where $\mathrm{EBRD}_{\mathrm{t}, \mathrm{j}}$ represents earnings per share before $\mathrm{R} \& \mathrm{D}$ or in other words EPS+RDPS;

Similarly to Green et al (1996), and Stark \& Thomas (1998), by adding book value as an independent variable in equation (3), might provide an equation form with a rather increased explanatory power for our dependent variable. Hence, we create the following equation (equation 4):

$$
P_{t, j}=a_{0}+a_{1} E B R D_{t, j}+\alpha_{2} \operatorname{RDPS}_{t, j}+\alpha_{3} B V P S_{t, j}+e_{t, j}
$$

Where, $B$ VPS $_{t, j}$ is the book value per share for financial year $t$ and firm $j$.

This last equation (equation 4) represents a linear relation between stock price (market value) and earnings, book value and R\&D. Stark (1997) provides a similar linear form of equation, but with the addition of dividends as an explanatory variable. Acknowledging the Clean Surplus Relation (CSR), dividends are omitted from our model ${ }^{10}$. The estimation of equations (3) and (4) and its subsequent results could provide us with noteworthy information.

Firstly, the estimation educed results can provide a statistically significant $\mathbf{a}_{2}$ coefficient. Such a finding could be interpreted in two different ways regarding the coefficient sign. If coefficient $\mathbf{a}_{2}$ is positive and statistically significant, then this can be interpreted as an indication that investors in Greece attribute value to $R \& D$ expenditures. Such a finding would also imply that the investing public expects an inflow of future benefits to the firm, due to the creation of assets that incorporate firm innovation.

If coefficient $\mathbf{a}_{2}$ is negative and statistically significant, then this can be acknowledged as an indication that the Greek investing public attributes negative value to $R \& D$ expenditures. This would mean that investors regard R\&D expenses not as a value bearing amount, but as an operational expense that is used by the firm's management for reasons other than creating innovation and subsequent benefits and growth. 
Another finding with interpretation similar to the latter, would be the case of $\mathbf{- a}_{\mathbf{1}} \mathbf{=} \mathbf{a}_{\mathbf{2}}$ coefficient. Such a result practically means that the market does not capitalize R\&D expenses. ${ }^{11}$ Those expenses are not treated as if they will bring in future benefits, but rather as expenses that have already occurred in the present financial year and have been accrued. In other words, they are treated as operational expenses. The estimation results can also provide us with statistically insignificant $\mathbf{a}_{2}$ coefficient. If this is the case, investors in Greece do not seem to attribute any value to $R \& D$ expenditures. Namely, they treat them neither as investments, nor as operational expenses since they believe that these expenses have no influence in the entity's creation of innovation and consequent development.

Furthermore, to the above mentioned research methodology, a robustness check is introduced in our empirical analysis, in an attempt to verify the statistically significant findings that may potentially arise from our multivariate regression analysis. This additional test, controls the validity of the R\&D expenditures coefficient by constructing a dummy variable and introducing it to equation (4), in order to substitute R\&D expenditures variable (RDPS). The dummy variable that will be created will use as a benchmark for comparison, the average (Mean) R\&D spending. In this way the formulated variable will equal 1 in the event of exceeding, or being equal to mean $R \& D$ spending and 0 in case of being below R\&D spending average.

Therefore, equation (4) with the substitution of RDPS by the new dummy variable DRD, formulates Equation (5) that can be depicted as follows:

$$
P_{t, j}=a_{0}+a_{1} E B R D_{t, j}+\alpha_{3} B V P S_{t, j}+\alpha_{4} D R D_{t, j}+e_{t, j}
$$

Where DRD is a dummy variable:

$D R D=1$, if $R \& D$ expenditures for firm $j$ on year $t \geq$ Mean $R \& D$ expenditures for year $t$, zero otherwise.

This reasoning attempts to provide an interpretation and validation of the regression results. The utilization of such a variable creates two distinct groups. The companies that record R\&D expenses equal or bigger than the average $R \& D$ spending constitute the group of firms that are considered more intensive in the production of Intangible assets, while the opposite applies for companies that record fewer $R \& D$ expenses than the average $R \& D$ spending.

If the coefficient of the RDPS variable, turns out to be statistically significant, (either with a positive or a negative sign) then the utilization of such a dummy variable and the estimation of equation (5), will provide the ability to verify whether the estimated outcome, is a result formulated by the companies that consider R\&D spending as an opportunity for future growth, or not. The following table (Table 1), provides a brief explanation of the potential outcomes of estimating equations (4) and (5).

Table 1 - Effects of the Estimated Coefficient Signs

\begin{tabular}{|c|c|c|}
\hline $\begin{array}{c}\text { Coefficient Sign } \\
\text { of RDPS } \\
\text { (Equation 4) } \\
\end{array}$ & $\begin{array}{c}\text { Coefficient Sign } \\
\text { of DRD } \\
\text { (Equation 5) }\end{array}$ & 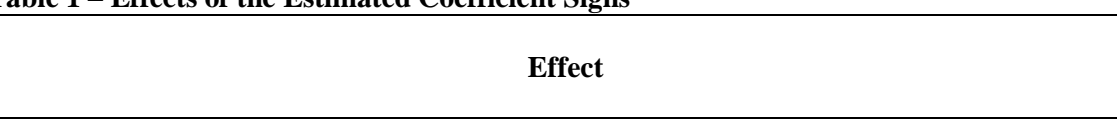 \\
\hline \multirow[b]{2}{*}{$(+)$} & $(+)$ & $\begin{array}{l}\text { The higher R\&D spending may be, the higher the stock price may rise. However if the } \\
\text { company spends below R\&D average the stock price will decrease. This might provide } \\
\text { evidence that the investors' perception towards } R \& D \text { can be affected negatively by } \\
\text { companies spending poorly on R\&D. }\end{array}$ \\
\hline & $(-)$ & $\begin{array}{l}\text { The higher R\&D spending may be, the higher the stock price may reach. Even if the company } \\
\text { spends below R\&D average the stock price will still increase. However if the company } \\
\text { spends too much (above R\&D average) the stock price will decrease. This might suggest that } \\
\text { the investors' perception towards R\&D can somehow be affected negatively by companies } \\
\text { spending on R\&D growth potential. }\end{array}$ \\
\hline \multirow{2}{*}{$(-)$} & $(+)$ & $\begin{array}{l}\text { The higher R\&D spending may be, the lower the stock price may reach. However if the } \\
\text { company spends above R\&D average the stock price will increase. This might provide } \\
\text { evidence that the investors' perception towards } R \& D \text { is positively affected by companies } \\
\text { investing on } R \& D \text { potential future benefits. }\end{array}$ \\
\hline & $(-)$ & $\begin{array}{l}\text { The higher R\&D spending may be, the lower the stock price may reach. However if the } \\
\text { company spends below R\&D average, this will increase the stock price. This might provide } \\
\text { evidence that the investors' perception towards } R \& D \text { is (paradoxically) positively affected by } \\
\text { companies spending poorly on R\&D. }\end{array}$ \\
\hline
\end{tabular}


Moreover, the estimation of both equations (3) and (4) can provide us with validation of whether the addition of Book Value and R\&D expenses produces incremental value for Greek public firms, consistent with similar findings in accounting literature.

\section{DATA AND SAMPLE SELECTION}

The sample used for analysis in this research consists only of public firms trading in Athens Stock Exchange (ASE) market for the years 2005-2010. Public firms were chosen as our sample, due to the fact that, only listed firms are obligated of disclosing their financial statements in accordance with IFRS. Non public firms were excluded, due to the inexistence of market values (stock prices) and the different accounting treatment that Greek GAAP present regarding R\&D expenses in comparison with IFRS. It must also be duly noted that IFRS have been adopted at 2005 and for this reason only 6 years of firm - year observations are available.

Our sample consists of those public companies that during the fiscal years, 2005 to 2010 have spent for $\mathrm{R} \& \mathrm{D}$ and therefore record $\mathrm{R} \& \mathrm{D}$ expenditures in their financial statements. When the annual subsamples are pooled together, the resulting sample is 208 firm - year observations. This initial sample is further decreased following Frankel \& Lee (1998), since we delete firms with negative book value that are assumed to be firms with uncertain future prospects. Our sample selection criteria results to a panel of 200 firm - year observations that is utilized for our empirical analysis. EPS, Book Value and R\&D expenditures were available by HELLASTAT databank, while adjusted Stock Price for Greek public firms came from the UOM Database. Finally, the weighted moving average number of stocks was hand collected from the financial statements.

Furthermore, it is important to mention that the stock prices used $(\mathrm{P})$, are not those of the last day of the fiscal year $\mathrm{t}$ but the price 3 months after that, namely March $31^{\text {st }}$ of year $t+1$. This reasoning is used, in order to include to the stock price, the influence of financial statements' announcement, which public companies have to prepare and present until the end of the third month after the end of the financial year.

Book Value (BVPS) is measured as the sum of shareholder's equity, plus reserves for year $t$ and it is sharedeflated for scaled effects. R\&D expenditures (RDPS), are recognized as items recorded in the income statement for year $t$ and deflated using weighted moving average number of shares at the same year. Earnings per share for year $t$, extracted by the Statement of firm's Financial Position, plus R\&D expenditures at the same year represent EBRD which depict the value of Earnings before R\&D expenditures.

Taking under consideration the above mentioned analysis, the following table is presented, depicting the descriptive statistics on selected variables of our sample.

Table 2 - Summary Statistics

\begin{tabular}{cccccc}
\hline Variable & Mean & Median & Std. Dev. & Minimum & Maximum \\
\hline PRICE & 2.78109 & 1.50092 & 3.33067 & 0.07 & 21.6 \\
$B V P S$ & 2.48912 & 1.77917 & 2.41087 & 0.004041 & 13.587 \\
RDPS & 0.0381 & 0.023294 & 0.04195 & $5.67 \mathrm{E}-06$ & 0.2248 \\
EBRD & 0.11718 & 0.107803 & 0.35353 & -1.76753 & 1.22061 \\
\hline
\end{tabular}

Notes: The sample consists of 200 firm year observations of stock price, book value per share, R\&D per share, earnings per share before $R \& D$ for the years 2005 to 2010. PRICE represents the stock market price taken from Athens Stock Exchange on March 31st, of each year. BVPS is firm's book value divided by the weighted moving average number of the firm's stocks. RDPS represents R\&D expenditures as recorded on the income statement divided by the weighted moving average number of the firm's stocks. EBRD variable constitutes earnings before $R \& D$ expenditures and it has been formed by adding EPS for each firm with R\&D expenditures divided by the weighted moving average number of firm's stocks.

This table displays graphically the characteristics of the variables used, namely PRICE, BVPS, EBRD and RDPS. It is evident, that some relatively extreme high and low values appear in our sample. Despite utilizing some sample selection criteria in order to limit the occurrence of extreme values, the existence of a small sample prevents us from further abridging it.

Furthermore it can be suggested from table 2, that $R \& D$ expenses present significantly minor amounts while at the same time the difference between minimum and maximum values together with the mean and median 
are skewed with a concentration of frequency distributions at the lower end. The same remarks can be made for PRICE and BVPS variables that present a similar frequency depiction, while the contrast comes from EBRD that presents skewness close to zero.

\section{REGRESSION RESULTS}

In order to extract empirical results for the case examined, a Pooled Ordinary Least Squares (OLS) regression has been implemented for the estimation of equations (3), (4) and (5). It has to be noted, that alternative estimation methods are applicable with our data sample. Both robust and maximum likelihood estimation techniques are applicable, but their requirements for symmetrical and normally distributed errors respectively, cannot be met in our case.

Our choice of estimation method was also consistent with the results of the panel diagnostic tests that were implemented and appear to confirm our choice in the matter of heterogeneity. More specifically, we have employed a Hausman test for all three equations, resulting in favor of Fixed Effects estimation in all cases ${ }^{12}$. Our next panel diagnostic test was the implementation of an F-test for joint significance of Fixed Effects, resulting to the adequacy of Pooled OLS regression estimation ${ }^{13}$ for the three equations ${ }^{14}$ over Fixed Effects estimation.

The regression analysis that has been employed was OLS, following White's approach (1980) for heteroscedasticity consistent standard errors and covariance. The outcomes of the estimated regressions can be seen in the following table (Table 3).

Table 3 - Pooled OLS estimates for Equations 3, 4 and 5

\begin{tabular}{|c|c|c|c|c|c|c|c|}
\hline & const & $E B R D$ & $R D P S$ & $B V P S$ & $D R D$ & $\operatorname{Adj.} R^{2}$ & Akaike \\
\hline Equation 3 & $\begin{array}{c}2.4145 * * * \\
(10.17)\end{array}$ & $\begin{array}{c}5.8999 * * * \\
(4.525)\end{array}$ & $\begin{array}{c}-8.6657 * * \\
(-2.183)\end{array}$ & & & 0.3271 & 972.59 \\
\hline Equation 4 & $\begin{array}{c}2.02978 * * * \\
(6.45)\end{array}$ & $\begin{array}{c}5.56676^{* * * *} \\
(4.111)\end{array}$ & $\begin{array}{c}-8.77918^{* *} \\
(-2.125)\end{array}$ & $\begin{array}{c}0.174121 * \\
(1.691)\end{array}$ & & 0.3383 & 970.21 \\
\hline Equation 5 & $\begin{array}{c}1.97017^{* * * *} \\
(6.44)\end{array}$ & $\begin{array}{c}5.54966^{* * * *} \\
(9.018)\end{array}$ & & $\begin{array}{c}0.17044 * * \\
(2.038)\end{array}$ & $\begin{array}{c}-0.74439^{*} \\
(-1.774)\end{array}$ & 0.3373 & 970.51 \\
\hline
\end{tabular}

Equation 3: $\quad P_{t, j}=a_{0}+a_{1} E B R D_{t, j}+\alpha_{2} R D P S_{t, j}+e_{t, j}$

Equation 4: $\quad P_{t, j}=a_{0}+a_{1} E_{B R D_{t, j}}+\alpha_{2} R D P S_{t, j}+\alpha_{3} B V P S_{t, j}+e_{t, j}$

Equation 5: $\quad P_{t, j}=a_{0}+a_{1} E_{B R D_{t, j}}+\alpha_{3} B V P S_{t, j}+\alpha_{4} D R D_{t, j}+e_{t, j}$

Notes: All models use PRICE as a dependent variable. PRICE represents the closing stock market price taken from Athens Stock Exchange on March 31st, of the year $t+1$. BVPS is firm's book value for year t divided by the weighted moving average number of the firm's stocks. RDPS represents $R \& D$ expenditures for year $t$ as recorded on the income statement divided by the weighted moving average number of the firm's stocks. EBRD variable constitutes earnings before $R \& D$ expenditures and it has been formulated by adding each firm's EPS for year $t$ with each firm's $R \& D$ expenditures for year $t$ divided by the weighted moving average number of firm's stocks. $D R D$ is a dummy variable that equals 1 if $R \& D$ expenditures for firm $j$ on year $t \geq$ Mean $R \& D$ expenditures for year $t$ and zero otherwise.

For all three equations the methodology of heteroscedasticity-consistent standard errors and covariance is utilized. Pooled OLS was employed with our data after rejecting the incorporation of Fixed or Random Effects. This was decided after conducting for both models an F-Test for joint significance of Fixed Effects and Hausman test.

$* * *, * *$ and $*$ represent a $1 \%, 5 \%$ and $10 \%$ statistical significance in the respective cases while the values in the parentheses depict the $t$-statistic value.

It is obvious from the OLS estimation results of equation (3), that the coefficients of variables EBRD and RDPS, as well as the intercept are statistically significant. The level of significance is estimated at $1 \%$, for coefficients of the intercept and EBRD, while RDPS bears a statistical significance of 5\%. The finding whose peculiarity seems to attract the attention in this estimation and differs from previous research findings, is the negative sign of RDPS coefficient. Its value is equal to a quite substantial -8.66, demonstrating a negative relation between stock prices and R\&D expenditures. The Adjusted $R^{2}$ of the equation's (3) estimation is 0.32 , presenting a reasonable degree of explanatory power, while the Akaike criteria is valued at 972.59.

The pooled OLS estimation for equation (4), presents similar findings with the previous equation. As depicted in Table 3 the coefficients of all variables, namely, EBRD, RDPS, BVPS, as well as the intercept appear to 
be statistically significant. The coefficients for the equation's intercept and EBRD variable, maintain the $1 \%$ level of significance, but with a vast drop of a rather noticeable $40 \%$ in the statistical significance of the intercept. The correlated omitted variable bias that occurs in Ohlson's model in the case of the intercept, that is being statistically significant, seems to apply here. The absence of an important variable from Equation (3) that is later incorporated in Equation (4), namely BVPS, seems to be responsible for this drop in the value of the $\mathrm{t}$ - statistic.

The table also suggests that RDPS and BVPS have a 5\% and 10\% level of significance, respectively. The Adjusted $\mathrm{R}^{2}$ of the equation's (4) estimation is 0.33 , demonstrating an improvement with the addition of BVPS on this estimation. Table 3, also provides us with a smaller figure of the Akaike criteria which is now equal to 970.21, presenting an improvement in comparison with equation (3) with the addition of BVPS variable. This finding suggests that the incorporation of BVPS variable, adds on the incremental value of the stock price, a result consistent with previous literature.

The finding that once more attracts the attention regarding RDPS variable, is the existence of a result analogous with what we observed in equation (3). A substantial figure equal to -8.77 is estimated, depicting once more a negative relation with the dependent variable. The value of the RDPS coefficient has not changed despite the introduction of a new variable to our equation.

The negative sign of the statistically significant estimation, regarding RDPS, is not consistent with previous findings, since it suggests an inverse relation between the innovation input, namely $R \& D$ expenses and stock price.

The estimation result of equation (4) regarding RDPS is validated by utilizing a robustness check that further analyses our model by estimating, with OLS regression analysis, equation (5). The estimates of this equation, present a statistical significance of $1 \%$ for both EBRD variable and the intercept, without a significant change on the coefficient values or signs. BVPS, is also statistically significant for $5 \%$, while Adjusted $\mathrm{R}^{2}$ and Akaike criterion are about the same with the estimation of Equation (4) resulting in 33\% and 970.51 respectively.

The estimate of the DRD dummy variable seems to verify the results of equation (4) estimation. The coefficient amounts at a statistically significant -0.74 , depicting once more a negative relation between R\&D spending and stock prices. This negative coefficient implies that the higher (above average) the R\&D spending may be for a firm, the bigger the negative effect may be on its stock price and vice versa, thus depicting a paradox that is not consistent with the previous literature and the growth potential that R\&D as an innovation creator might imply.

Investing public in Greece does not seem to value $R \& D$ expenditures as a value creator for both the firm and the economy and seem to believe that future benefits cannot flow towards the firm that invests in innovation. As a matter of fact, estimation of equation (5) incorporates a new perspective, suggesting that if a company spends below R\&D spending average, this will result in an increase of the stock price, implying that investors' perception towards $R \& D$ is positively affected by companies spending poorly on $R \& D$.

\section{CONCLUSIONS}

This paper attempts to examine whether investors value the potential of Greek enterprises to produce innovation. The question at hand can be else wise summarized in whether investors are affected in their decision for buying or selling a stock, by the growth prospect that innovation, expressed with R\&D spending, creates for an enterprise.

R\&D expenditures are the main focus of this empirical study, since they represent the enterprise's input for the creation of innovation and therefore the effort for future development and firm growth.

Our empirical analysis, using a Eurozone country in economic turmoil, depicts the corporate rationale behind the creation of innovation through R\&D spending. The outcomes of our estimation depict that Research and Development expenditures, play the role of anything but the innovation creator, at least in the minds of the investors.

Our findings are consistent with previous literature in terms of utilizing a methodology like the one that Stark \& Thomas (1998) do, and the incorporation of BV as an improvement of the initial model. Our results are also 
consistent with previous literature, in terms that the investing public attributes value in R\&D expenditures. The difference that draws attention in Greek economic reality, as mentioned earlier, is that investors attribute a negative value in public firms' $R \& D$ spending. Not only do they not consider that $R \& D$ expenditures can produce innovation that will result in future growth, but they also seem to be affected negatively in their assessment of the firm's financial condition. The less a company seems to spend for R\&D the better it may be.

Perhaps, even this small amount of business sector created intangibles in Greece, cannot be perceived as a competitive advantage, making firms investing on them, distinguishable in the minds of the investing public. Perhaps, either the small magnitude of business sector R\&D, raises doubts for the ability of Greek firms to create innovation and consequently grow and raise value, or the innovation created constitutes innovation via adoption, a fact that if true, raises an important question for the general growth and well being of the Greek private sector and subsequently for the Greek economy as a whole.

\section{ACKNOWLEDGMENTS}

The authors would like to thank Professor Negakis I.C., Assistant Professor Kousenidis D., Dr. Ladas A. for their great help and comments during the preparation of this paper, as well as the two anonymous referees for their valuable remarks.

\section{AUTHOR INFORMATION}

Panayiotis Tahinakis is an Assistant Professor of Accounting, Department of Accounting and Finance at the University of Macedonia, Economic and Social Sciences, Thessalonica, Greece, and a Tutor at the Hellenic Open University. He holds a Ph.D. in Accounting, a M.Sc. in Accounting and a B.A. in Business Administration. He has worked for 10 years in the public and private sectors and has taught for 12 years in several Universities in Thessalonica, Greece. He has published articles in academic journals and has participated in many international conferences. (E-mail: tahi67@uom.gr, tel.: +302310891564, 156, Egnatia str., 540-06, Thessaloniki, Greece. Corresponding Author)

Michalis Samarinas is a PhD Candidate in the Department of Accounting and Finance at the University of Macedonia, Economic and Social Sciences, Thessalonica, Greece and an adjunct Lecturer for the Empire State College/ State University of New York, and the Institut Universitaire Kurt Bosch. He is an accountant and tax consultant certified by the Greek Ministry of Finance, working as an independent consultant in the private sector. He has participated in many international conferences. (E-mail: msamarinas@uom.gr, tel.: +302310891564, 156, Egnatia str., 540-06, Thessaloniki, Greece)

\section{REFERENCES}

1. Al-Horani A., Pope P. F. \& Stark A. W. (2003), "Research and development activity and expected returns in the United Kingdom", European Financial Review, 7(1) 27-46.

2. Arnold L. G., (2000), "Endogenous growth with physical capital, human capital and product variety: A comment", European Economic Review, 44(2) 1599-1605.

3. $\quad$ Arrow, K. J. (1962),"Economic Welfare and the Allocation of Resources for Invention," in Richard R. Nelson, ed., "The Rate and Direction of Inventive Activity". Princeton, NJ: Princeton University Press, 609- 626.

4. $\quad$ Acs Z. J. \& Audretsch D. B., (1988), "Innovation in Large and Small Firms: An Empirical Analysis", The American Economic Review, 78(4) 678-690.

5. $\quad$ Baber, W., Fairfield P. \& Haggard J., (1991). "The Effect of Concern about Reported Income on Discretionary Spending Decisions: The Case of Research and Development". The Accounting Review, 66(4) 818-829.

6. Barth, M.E. \& Clinch, G. (2009), "Scale Effects in Capital Market's-Based Accounting Research”, Journal of Business Finance \& Accounting, 36(3) (4) 253-288.

7. Brown J. R., Fazzari S. M. \& Petersen B. C., (2009), "Financing Innovation and Growth: Cash Flow, External Equity, and the 1990s R\&D Boom", The Journal of Finance, 64(1) $151-185$. 
8. Bushee, B., (1998), "The Influence of Institutional Investors on Myopic R\&D Investment Behavior”, The Accounting Review, 73(3) 305-333.

9. Chambers, D., Jennings R, \& Thompson R. B., (2002). “Excess returns to R\&D intensive firms”, Review of Accounting Studies, 7(2)(3) 133-158.

10. Chan, S.H., Martin J.D. \& Kensinger J.W., (1990), “Corporate Research and Development Expenditures and Share Value", Journal of Financial Economics, 26(2) 255-276.

11. Chan L.K.C., Lakonishok J. \& Sougiannis T., (2001), "The Stock Market Valuation of Research and Development Expenditures", The Journal of Finance, 56(6) 2431-2456.

12. Chauvin, K.W. \& Hirschey M., (1993), "Advertising, R\&D Expenditures and the Market Value of the Firm", Financial Management, 22(4) 128-140.

13. Deng Z. \& Lev B, (2006), "In-Process R\&D: To Capitalize or Expense?”, Journal of Engineering and Technology Management, 23(1) (2) 18-32.

14. Ely.K, Simko P. J. \& Thomas.L.G., (2003), "The usefulness of biotechnology firms' drug development status in the development of research and development costs", Journal of Accounting Auditing and Finance, 18(1) 163-196.

15. Fama E. F. \& French K. R., (1998), “Taxes, Financing Decisions, and Firm Value”, The Journal of Finance, 53(3) 819-843.

16. Frankel R. \& Lee C. M., (1998), “Accounting Valuation, Market Expectation, and Cross-Sectional Stock Returns", Journal of Accounting and Economics, 25(3) 283-319.

17. Franzen L. \& Radhakrishnan S., (2009), "The Value Relevance of R\&D Across Profit and Loss Firms", Journal of Accounting and Public Policy, 28(1) 16 - 32.

18. Funke M. \& Strulik H., (2000), "On endogenous growth with physical capital, human capital and product variety", European Economic Review, 44(3) 491- 515.

19. Green, J.P., Stark A.W. \& Thomas H.M. (1996), "UK Evidence on the Market Valuation of Research and Development Expenditures", Journal of Business Finance \& Accounting, 23(2) 191-216.

20. Grossman G. M. \& Helpman E., (1991), "Quality Ladders in the Theory of Growth”, The Review of Economic Studies, 58(1) 43-61.

21. Hand. J. R. M. (2005). "The value relevance of financial statements in the venture capital market", The Accounting Review, 80(2) 613-648.

22. Hirschey,M. (1982), "Intangible Capital Aspects of Advertising and R\&D Expenditures", Journal of Industrial Economics, 30(4) 375-389.

23. Hirschey,M. (1985),"Market Structure and Market Value”, Journal of Business, 58(1) 89-98.

24. Hirschey,M. \& Weygandt J.J. (1985), "Amortization Policy for Advertising and Research and Development Expenditures", Journal of Accounting Research, 23(1) 326-335.

25. Hirschey,M. \& Spencer R.S. (1992), "Size Effects in the Market Valuation of Fundamental Factors", Financial Analysts Journal, 48(2) 91-95.

26. Howitt P., (1999), "Steady Endogenous Growth with Population and R \& D Inputs Growing", Journal of Political Economy, 107(4) 715-730.

27. Kallunki J. P., Pyykko E. \& Laamanen T., (2009), "Stock Market Valuation, Profitability and R\&D Spending of the Firm: The Effect of Technology Mergers and Acquisitions", Journal of Business Finance \& Accounting, 36(7) 838-862.

28. Kothari, S. P., Laguerre T. E. \& Leone A. J. (2002), "Capitalization versus expensing: Evidence on the uncertainty of future earnings from capital expenditures versus R\&D outlays", Review of Accounting Studies, 1(4) 355-382.

29. Lev B \& Sougiannis T., (1996), The capitalization, amortization, and value-relevance of R\&D, Journal of Accounting and Economics, 21(1) 107-138.

30. Mairesse J. \& Mohnen P., (2002), “Accounting for Innovation and Measuring Innovativeness: An Illustrative Framework and an Application", The American Economic Review, 92(2) Papers and Proceedings of the One Hundred Fourteenth Annual Meeting of the American Economic Association 226230.

31. Ohlson J., (1995), "Earnings, book values and dividends in security valuation", Contemporary Accounting Research, 11(2) 661-687.

32. Oswald D. R. \& Zarowin P., (2007), "Capitalization of R\&D and the Informativeness of Stock Prices", European Accounting Review, 16(4) 703-726. 
33. Oswald D. R., (2008), “The Determinants and Value Relevance of the Choice of Accounting for Research and Development Expenditures in the United Kingdom”, Journal of Business Finance \& Accounting, 35(1) $1-24$.

34. Palmon D. \& Yezegel A, (2010), "R\&D Intensity and the Value of Analysts' Recommendations", Contemporary Accounting Research, 20(10) 1-34.

35. Sougiannis, T. (1994), "The Accounting Based Valuation of Corporate R\&D", The Accounting Review, 69(1) 44-68.

36. Stark, A.W., (1997), "Linear Information Dynamics, Dividend Irrelevance, Corporate Valuation and the Clean Surplus Relationship”, Accounting \& Business Research, 27(3) 219-228.

37. Stark, A.W. \& H.M. Thomas (1998), “On the Empirical Relationship Between Market Value and Residual Income in the UK", Management Accounting Research, (9) 445-60.

38. Xu B., Magnan M.L. \& Andre P.E., (2007), "The Stock Market Valuation of R\&D Information in Biotech Firms", Contemporary Accounting Research, 24(4) 1291-1318.

\section{ENDNOTES}

${ }^{1}$ An earlier version of this paper has been presented at the $3^{\text {rd }}$ International Conference on Accounting and Finance in Skiathos, Greece, $26^{\text {th }}-27^{\text {th }}$ of August 2010.

${ }^{2}$ We refer to the knowledge that can potentially be capitalized and constitute an intangible asset. For example a computer software that incorporates knowledge for a specific production procedure.

3 e.g. patents, copyrights, trademarks

${ }^{4}$ IAS $38, \S 10, \S 21, \S 57$

${ }^{5}$ IAS 38 provisions determine the general recognition criteria for the creation of identifiable Intangible Assets. $§ 10$ and $\$ 21$ provide the following criteria that need to be satisfied:

a) The created Intangible Asset must be identified separately from other aspects of the business entity.

b) The use of the created Intangible Asset must be controlled by the entity that creates it as a result of its past actions and events.

c) There must be future economic benefits expected to flow to the entity from the creation of the Intangible Asset.

d) The cost of the created Intangible asset must be measured in a reliable way.

Moreover IAS 38, $\$ 57$ refers specifically on the additional recognition criteria that needs to be satisfied in order to capitalize the Development expenses. So the entity must demonstrate all the following:

a) Technical feasibility of completing the intangible asset.

b) Intention to complete the Intangible asset and either use it or sell it.

c) The ability to use or sell the created asset.

d) The capacity of the created intangible asset to generate future economic benefits.

e) The entity's ability to measure in a reliable manner the costs incurred for the creation of the Intangible Asset.

${ }^{6}$ Of course it needs to be stated that once costs have been expensed during the development phase they can no longer be capitalized.

7 The data have been extracted from the Eurostat database. The years 2008 and 2009 for Greece are projections made by the International Statistical Yearbook.

$8 \&$ Dintensity $=\frac{R \& \text { Dexpenditures }}{\text { Sales }}>0,01$

${ }^{9}$ We utilize weighted moving average number of stocks for the variables utilized.

${ }^{10}$ This reasoning is used, in order to include to the stock price, the influence of financial statements' announcement.

${ }^{11}$ A similar approach is followed by Stark and Thomas (1998)

${ }^{12}$ In this case equation (3) becomes as follows with $-\mathrm{a}_{1}=\mathrm{a}_{2}$ : $P_{t}=a_{0}+a_{1}\left(E P S_{t}+R D_{t}\right)+\alpha_{2} R D_{t}+\alpha_{3} B V_{t} \Leftrightarrow P_{t}=a_{0}+a_{1} E P S_{t}+a_{1} R D_{t}+\alpha_{2} R D_{t}+\alpha_{3} B V_{t}$

$P_{t}=a_{0}-a_{2} E P S_{t}-a_{2} R D_{t}+\alpha_{2} R D_{t}+\alpha_{3} B V_{t} R D$ are eliminated, so:

$P_{t}=a_{0}-a_{2} E P S_{t}+\alpha_{3} B V_{t}$

${ }^{13}$ Hausman test statistic Equation (3):

$\mathrm{H}=10.3537, \mathrm{p}$-value $=0.005645$ in favor of the fixed effects model. 
Hausman test statistic Equation (4):

$\mathrm{H}=14.5258$, p-value $=0.00227015$ in favor of the fixed effects model.

Hausman test statistic Equation (5):

$\mathrm{H}=14.2981$, $\mathrm{p}$-value $=0.00252617$ in favor of the fixed effects model.

${ }^{14} \mathrm{~F}-\mathrm{Test}$ : equation (3)

$\mathrm{F}(44,153)=1,05632$ with $\mathrm{p}$-value 0,39295 accepting the null hypothesis that Pooled OLS is adequate

F-Test: equation (4)

$\mathrm{F}(44,152)=1,10622$ with $\mathrm{p}$-value 0,321296 accepting the null hypothesis that Pooled OLS is adequate

F-Test: equation (5)

$\mathrm{F}(44,152)=1,1414$ with $\mathrm{p}$-value 0,275655 accepting the null hypothesis that Pooled OLS is adequate

${ }^{15}$ A Breusch-Pagan test was not performed since the Hausman test had already rejected the implementation of Random Effects Estimation. 


\section{NOTES}

